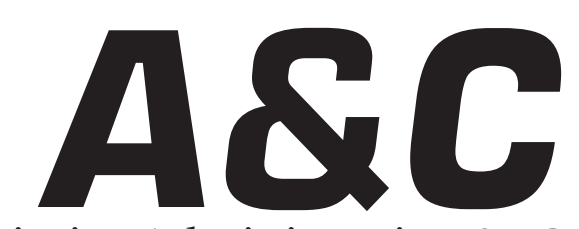

Revista de Direito Administrativo \& Constitucional

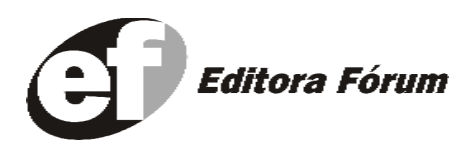

A\&C R. de Dir. Administrativo e Constitucional, Belo Horizonte, ano 4, n.15, p.1-256, jan./mar. 2004 
A\&C REVISTA DE DIREITO ADMINISTRATIVO E CONSTITUCIONAL

\section{IPDA}

Instituto Paranaense

de Direito Administrativo

Direção Geral

Romeu Felipe Bacellar Filho

Direção Editorial

Paulo Roberto Ferreira Motta

Direção Executiva

Emerson Gabardo

Conselho de Redação

Edgar Chiuratto Guimarães

Adriana da Costa Ricardo Schier

Célio Heitor Guimarães

Conselho Editorial

\begin{tabular}{|c|c|}
\hline Adilson Abreu Dallari & Manoel de Oliveira Franco Sobrinho \\
\hline Alice Gonzáles Borges & (in memoriam) \\
\hline Carlos Ari Sundfeld & Marçal Justen Filho \\
\hline Carlos Ayres Britto & Marcelo Figueiredo \\
\hline Carlos Delpiazzo & Márcio Cammarosano \\
\hline Lúcia Antunes Rocha & Maria Cristina Cesar de Oliveira \\
\hline de Mello & Nelson Figueiredo \\
\hline èmerson Merlin Clève & Odilon Borges Junior \\
\hline Enrique Silva Cimma & Pascual Caiella \\
\hline Eros Roberto Grau & Paulo Eduardo Garrido Modesto \\
\hline Fabrício Motta & Paulo Henrique Blasi \\
\hline ilhermo Andrés Muñoz & Paulo Ricardo Schier \\
\hline Jorge Luís Salomoni & Pedro Paulo de Almeida Dutra \\
\hline José Carlos Abraão & Regina Maria Macedo Nery Ferrari \\
\hline uardo Martins Cardoso & Rogério Gesta Leal \\
\hline José Luís Said & Rolando Pantoja Bauzá \\
\hline José Mario Serrate Paz & Sérgio Ferraz \\
\hline Pablo Cajarville Peruffo & Valmir Pontes Filho \\
\hline Juarez Freitas & Yara Stropa \\
\hline Julio Rodolfo Comadira & Weida Zancanne \\
\hline
\end{tabular}

Lúcia Valle Figueiredo

Luís Enrique Chase Plate

Os conceitos emitidos em trabalhos assinados são de responsabilidade de seus autores, que gozam de inteira

liberdade de opinião. e-mail para remessa de artigos, pareceres e contribuições: e.gab.@uol.com.br

ou conselho@editoraforum.com.br Endereço para envio de contribuições: Editora Fórum

Revista A\&C, Av. Afonso Pena, 2770, 15\%16 a andar, Funcionários, CEP 30130-007 - Belo Horizonte - MG

A\&C Revista de Direito Administrativo e Constitucional. Ano 3, n. 11, jan./mar. 2003. Belo Horizonte: Fórum, 2003.

Trimestral

ano 1, n.1, 1999 até ano 2, n.10, 2002 publicada pela Editora Juruá em Curitiba

ISSN: 1516-3210

1. Direito Administrativo. 2. Direito Constitucional. I. Fórum.

CDD: 342 CDU: 33.342
Editor responsável: Luis Cláudio Rodrigues Ferreira Projeto gráfico: Luis Alberto Pimenta

Diagramação: Luis Alberto Pimenta

Revisora: Olga M. A. Sousa

Pesquisa jurídica: Fátima Ribeiro - OAB/MG 74868 Bibliotecária: Nilcéia Lage de Medeiros -

CRB 1545/MG - 6 a região

(c) Editora Fórum Ltda., 2003.

Proibida a reprodução total ou parcial desta obra, por qualquer meio eletrônico, inclusive por processos xerográficos, sem autorização expressa do editor.

Distribuída em todo o território nacional

Assinaturas e comercialização:

Editora Fórum, Av. Afonso Pena, 2770, 15-16 andar, Funcionários, CEP 30130-007 - Belo Horizonte - MG Tel.: (31) 2121-4900 - 0800 704-3737

e-mail: editoraforum@editoraforum.com.br site: www.editoraforum.com.br 


\title{
El Servicio Público como Título Jurídico Exorbitante
}

\author{
Julio Rodolfo Comadira
}

\begin{abstract}
Sumario: Los supuestos dos modelos del Derecho Administrativo - El Derecho Administrativo como instrumento de gestión y de garantía - Un mismo hecho político determina dos sistemas jurídicos diferentes - Las bases iniciales del Derecho Civil individualista - Las bases iniciales del Derecho Administrativo individualista - Las transformaciones del Derecho Civil y del Derecho Administrativo - El Derecho Administrativo como instrumento de conformación social - El servicio público como título prestacional o de policía - Los primeros servicios públicos. Beneficencia, educación, salud, correos - Los servicios públicos económicos. La Concesión - Los poderes exorbitantes del servicio público como criterio de determinación de la jurisdicción contenciosa en Francia y como delimitación del Derecho Administrativo - La teorización del servicio público por la Escuela de Burdeos y la prerrogativa - El ocaso de la concesión. La asunción directa de las actividades económicas. La primera crisis de la noción de servicio público - El repliegue empresarial del Estado y la ola privatizadora. Una nueva crisis del concepto servicio público, de signo inverso - La situación en nuestro país. La Constitución de 1853-60 - La figura de la concesión - El cambio operado por la Constitución de 1949 - La situación en la década del 90 - La reforma constitucional de 1994 - El sistema de los servicios públicos en la reforma de 1994 - ¿Titularidad, asunción subsidiaria o Policía? - El Servicio Público en cuatro marcos regulatorios - Las consecuencias jurídicas de la caracterización ¿Régimen jurídico unitario? Pautas para su posible determinación. a) El título de acceso a la actividad. b) La duración de la habilitación - Los datos del servicio público: obligatoriedad y prestación garantizada
\end{abstract}

\section{Los supuestos dos modelos del Derecho Administrativo}

Han señalado dos autores ingleses ${ }^{1}$ que los diversos sistemas legales de Derecho Administrativo pueden ser reducidos a dos modelos: el de control y el instrumental.

El primero, de origen individualista, consideraría como función esencial del Derecho Administrativo el control o limitación de la Administración Pública por medio de los Tribunales, en tanto modo de garantizar los derechos e intereses de los ciudadanos. La expresión más acabada de esta visión sería la expuesta por Dicey² en Inglaterra a fines del siglo XIX.

El segundo modelo, en cambio, partiría del interés público como

\footnotetext{
Harlow, Carol and Rawling, Richard, Law and Administration, London, 1984, citado por Estella de Noriega, Antonio, en obra colectiva Manual de Derecho administrativo Comunitario, Madrid, Centro de Estudios Ramón Areces, 2000, pág. 3.

2 Estella de Noriega, Antonio, en obra colectiva, cit. pág. 3.
} 
eje teleológico del accionar administrativo y, desde esa perspectiva, hallaría en el Derecho Administrativo no únicamente un modo de controlar a la Administración, sino, además, un instrumento de ésta para la gestión del interés público. Su paradigma sería el Derecho Administrativo francés. ${ }^{3}$

\section{El Derecho Administrativo como instrumento de gestión y de garantía}

Desde mi punto de vista el Derecho Administrativo no puede ser entendido sino como un instrumento de preservación de prerrogativas estatales y de garantía de derechos individuales. El Derecho Administrativo es, simultáneamente, poder y libertad, prerrogativa y garantía. Por eso, el denominado modelo de control, no es, en realidad, Derecho Administrativo, en tanto éste sólo tiene sentido como juridicidad autónoma cuando, a la función de garantía suma, también, la de prerrogativa. El Derecho Administrativo es, a mi juicio, la expresión jurídica del poder administrativo limitado por la garantía.

\section{Un mismo hecho político determina dos sistemas jurídicos diferentes}

Esta concepción del Derecho Administrativo, que supone una configuración diferente de la propia del derecho privado, aparece desde sus mismos orígenes. Es curioso, afirma Garrido Falla, ${ }^{4}$ cómo, a partir de un mismo hecho histórico político - la Revolución Francesa - emergen dos sistemas jurídicos de conformación estructural diferente. Y más aún, me permito agregar: en los dos casos al amparo de una misma ideología: el individualismo liberal.

\section{Las bases iniciales del Derecho Civil individualista}

Así, pues, el Derecho Privado, que se plasma en el Código de Napoleón, se asienta sobre las siguientes bases:

a) La igualdad jurídica de las partes, con indiferencia respecto de la posible desigualdad económica;

b) La autonomía de la voluntad de las partes como factor jurígeno fundamental, expresada en sus dos manifestaciones típicas: libertad para contratar y libertad de contratar;

\footnotetext{
3 Estella de Noriega, Antonio, en obra colectiva, cit., págs. 2, 3, 7 y sigs.

4 Garrido Falla, Fernando, Las Transformaciones del régimen administrativo, $2^{a}$ ed., Madrid, Estudios de Administración, 1962, pág. 44.
}

A \& C R. de Dir. Administrativo e Constitucional, Belo Horizonte, ano 4, n. 15, p. 79-106, jan./mar. 2004 
c) Los derechos subjetivos de contenido patrimonial como absolutos, sin más límite que las exigencias derivadas del orden público, la moral pública y los derechos de terceros (artículo 19 de la Constitución Nacional);

d) La capacidad como libertad en principio incondicionada. Lo no prohibido estará permitido de modo que todo lo querido será, por ese solo hecho, lícito.

\section{Las bases inicialies del Derecho Administrativo individualista}

El Derecho Administrativo reconocerá, a su vez, incluso en la configuración inicial de sus instituciones las siguientes bases valorativas:

a) La desigualdad jurídica de las partes en la relación jurídico administrativa.

Es inherente, así, al Derecho Administrativo la consagración de la prerrogativa como situación de supraordenación jurídica de la Administración en relación con el administrado. Las prerrogativas como los privilegios, dice Maurice Hauriou, fueron desterradas por la revolución de las relaciones sociales, pero no del plano de las relaciones políticas; al contrario, se concentraron en el Gobierno y en la Administración de modo que desde entonces el Derecho Civil se asentó en la igualdad y el Derecho Administrativo en la prerrogativa. Es más, dice Hauriou, la existencia de un Derecho Administrativo de poder es la condición para la existencia de un Derecho Civil sin desigualdades. ${ }^{5}$ Ya se verá, cómo, al final de éste estudio, volveré sobre esta idea fundamental.

b) La exclusión de la autonomía de la voluntad de las partes como factor esencialmente productor de los vínculos obligacionales.

El contrato administrativo expresa, en ese sentido, la negación de aquel dogma privado en la medida em que la técnica predominante de su gestación es la adhesión del administrado a las cláusulas predeterminadas unilateralmente por la Administración.

c) Los derechos subjetivos patrimoniales condicionados por el interés público.

Tanto el derecho de propiedad privada, en general, como los derechos de contenido patrimonial originados por actos o contratos administrativos, en particular, están condicionados por el interés público y sujetos, por ende, a la expropiación y a la revocación por razones de oportunidad, mérito o conveniencia, respectivamente. d) La competencia de base normativa en tanto derivación del principio de
${ }_{5}$ Boquera Oliver, José M., Derecho Administrativo y Socialización, Madrid, Estudios Administrativos, 1965, pág. 49/50 citando a Maurice Hauriou, Precis, elementaire de Droit Administratif, 12 ed., Sirey, París, 1930, Préface.

A \& C R. de Dir. Administrativo e Constitucional, Belo Horizonte, ano 4, n. 15, p. 79-106, jan./mar. 2004 


\section{legalidad.}

La actuación de la Administración no es libre; el sentido originario del principio de legalidad radica, precisamente, en derivar esa actuación de la ley y del resto del ordenamiento válidamente generado.

\section{Las transformaciones del derecho civil y del Derecho Administrativo}

El Derecho no es indiferente a los cambios sociales, políticos y económicos. Y, por eso, tanto en el Derecho Privado como en el Derecho Público las transformaciones operadas a lo largo de los siglos XIX y XX determinaron en ambos modificaciones profundas.

El Derecho Privado fue asimilando, progresivamente, el impacto de exigencias superadoras del nivel ético de las relaciones jurídicas. La reforma del Código Civil Argentino en 1968 es, en ese aspecto, un testimonio elocuentemente revelador. La inhabilitación del pródigo, ${ }^{6}$ la lesión subjetiva, ${ }^{7}$ el abuso de los derechos, ${ }^{8}$ la teoría de la imprevisión ${ }^{9}$ o la mutabilidad de la cláusula penal, ${ }^{10}$ todas ellas instituciones positivizadas legalmente con la mencionada reforma son muestras de la existencia de un nuevo concepto en la moral jurídico privada de las relaciones civiles. ${ }^{11}$

El Derecho Público en general y el Derecho Administrativo en especial, por su lado, también experimentaron la incidencia de las nuevas corrientes. El estudio histórico de ciertas prerrogativas estatales pone de relieve esa circunstancia. Un libro de Oyhanarte ${ }^{12}$ (a quien sigo en los próximos tres párrafos) lo evidencia con toda lucidez.

La potestad expropiatoria inicialmente concebida como un modo de trasladar, por razones de interés público, bienes privados al ámbito público a través de la "compraventa forzosa" (nota al art. 1324, cód. civil), integra, con el tiempo, como variantes válidas de su ejercicio, a las denominadas expropiaciones no estatizantes, consistentes en la trasferencia de un bien privado a otro patrimonio privado, también por razones de interés público.

La potestad impositiva va a evolucionar de una visión que la entiende

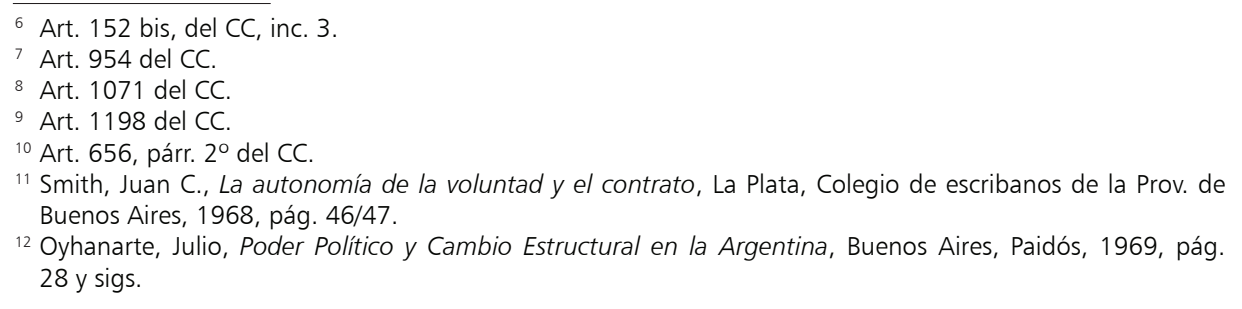

A \& C R. de Dir. Administrativo e Constitucional, Belo Horizonte, ano 4, n. 15, p. 79-106, jan./mar. 2004 
como un instrumento exclusivamente dirigido al logro de recursos para la hacienda estatal, a una valoración que la considera medio irrenunciable de política económica.

Y el poder de policía, concebido en sus inicios como limitación de derechos sólo fundable en la protección de la seguridad, la salubridad y la moralidad, va a reconocer, después, no sólo la validez de su orientación teleológica orientada a la promoción genérica de la prosperidad pública y el bienestar general, sino, incluso, la del poder de policía de emergencia en cuanto restricción - no extinción, al menos en la teoría - de derechos de intensidad profundizada a causa de la situación extraordinaria generada por la emergencia.

\section{El Derecho Administrativo como instrumento de conformación social}

Prerrogativa y garantía se presentan, así, como técnicas que, al influjo de los valores sociales, políticos y económicos cambiantes, constituyen instrumentos de conformación social. Esta evolución del Derecho Administrativo demuestra que esta rama del derecho, instrumento de poder juridizado, no es neutral ni indiferente ante los fines del Estado. ${ }^{13}$

$Y$ es ésta una realidad que se puede apreciar en general en las instituciones administrativas y, en especial, en el servicio público.

\section{El servicio público como título prestacional o de policía}

Quien se introduce en el estudio del servicio público advierte inmediatamente que si alguna coincidencia existe entre quienes han estudiado el concepto, ella es la de su absoluta equivocidad. Se ha dicho, incluso, que hay tantos conceptos del servicio público como autores se han ocupado de él.

Es posible, sin embargo, intentar la búsqueda de un dato unitario que, por estar presente en todas las nociones, permita identificar un elemento común caracterizador. Y ese dato es, a mi modo de ver, la del poder, esto es, la de la potestad al servicio de la prestación.

Adelanto, por ello, desde ahora que, en mi opinión, el servicio público es un título jurídico en sí mismo exorbitante, invocable por el Estado para asumir la titularidad de competencias prestacionales con el fin de ejercerlas

\footnotetext{
13 Villar Palasi, José Luis, La actividad industrial del Estado en el Derecho Administrativo, RAP, Madrid, n 3, pág. 53 y sigs., esp. pág. 57.
}

A \& C R. de Dir. Administrativo e Constitucional, Belo Horizonte, ano 4, n. 15, p. 79-106, jan./mar. 2004 
en forma directa (por administración) o indirecta a través de órganos personificados pública (v. gr.: entes autárquicos) o privadamente (v. gr.: sociedades anónimas); para desarrollarlas subsidiariamente en ausencia de prestadores privados, sin titularizarlas en sentido propio, o bien para ejercer su poder de policía sobre actividades privadas prestacionales, con el objeto de dar satisfacción o, en su caso, de asegurar la satisfacción de necesidades consideradas esenciales para el logro del bien común.

La titularidad, o no, de la actividad que se emprende o regula y la determinación de las necesidades que, en cada caso, justifican la decisión estatal de prestar o regular, son cuestiones históricamente contingentes que no alteran el dato de esencia siempre concurrente, esto es, la invocación de un título jurídico que implica, en sí, el empleo del poder, de la prerrogativa - con arreglo a contenidos también variables - para brindar una prestación que se estima ligada con inmediatez al bien común, o asegurar que ella se brinde.

Mairal $^{14}$ se ha referido, entre nosotros, a la ideología del servicio público. Y, en rigor, la ideología que aquí está en juego es la del Derecho Administrativo porque éste es, en realidad, el instrumento que afirma la prerrogativa, y su contrapunto, la garantía, no sólo en materia de servicio público, sino también en todo el campo del ejercicio de la función administrativa. Cuestionar, por ello, la ideología del servicio público es, en el fondo, cuestionar la esencia misma del Derecho Administrativo.

\section{Los primeros servicios públicos Beneficencia, educación, salud, correos}

El cierto que actividades que muy genéricamente podrían considerarse servicios públicos son hallables antes de la consagración del constitucionalismo (Justicia, Defensa, Relaciones Exteriores), pero su prestación estaba en realidad desprovista de toda significación servicial pues con ellos se trataba de atender a las necesidades del aparato estatal, antes que proporcionar utilidad a los súbditos. ${ }^{15}$

Cuando en el continente europeo se derrumba el Estado de Policía a partir de la consagración de los principios inspiradores de la Revolución Francesa, la concepción liberal impone un modelo de Estado en el cual la policía no excede el fin de mantener el orden y la seguridad de la res pública,

\footnotetext{
${ }^{14}$ Mairal, Héctor, La ideología de los servicios públicos, RDA, № 14, pág. 359 y sigs.

15 Santamaria Pastore, Juan A., Principios de derecho administrativo, Madrid, Centro de Estudios Ramón Areces, vol. II, 2002, pág. 301.
}

A \& C R. de Dir. Administrativo e Constitucional, Belo Horizonte, ano 4, n. 15, p. 79-106, jan./mar. 2004 
el orden público material, el orden de las "calles", en suma. Al mismo tiempo, abolidos los derechos feudales, se otorga a la sociedad el dominio de la vida económico social, dejando a los ciudadanos, individualmente, la responsabilidad de la satisfacción de sus necesidades. Esta concepción indiferente a la justicia de la conformación comunitaria y, en apariencia, no intervencionista y neutra, implicaba, por reversión de sentido, una intervención omisiva a favor de los sectores más poderosos de la sociedad. ${ }^{16}$

Había, no obstante, factores históricos derivados de la dinámica de los cambios, que condujeron, ya en aquel momento, a que el Estado asumiera por razones ideológicas o por conveniencia la satisfacción de necesidades generales hasta ese momento atendidas por la Iglesia, las órdenes religiosas, ${ }^{17}$ las corporaciones, las fundaciones, las universidades y otras instituciones sociales intermedias representativas del cuerpo social en el Antiguo Régimen. ${ }^{18}$

La asistencia, la sanidad, la educación, el correo (cuando deja de ser un servicio exclusivo al rey), son, así, en esa primera etapa, servicios asumidos por el Estado; empero, no se advierte en esa instancia vocación de publicatio, ni de monopolio, ni de exclusividad aunque sí es posible encontrar, como excepción, fundamentos políticos ideológicos para hacer de la enseñanza un monopolio estatal, como ocurrió en Francia, donde esta función fue considerada un instrumento de igualación social ${ }^{19} \mathrm{y}$ de consolidación republicana. ${ }^{20}$ El carácter no monopolístico del servicio explica, precisamente, la no aparición, todavía, de la figura de la concesión. ${ }^{21}$

De todos modos la actuación coactiva del Estado, su vigorosa presencia al servicio de una burguesía afirmada al compás de la neutralización de las corporaciones, ya suponía el empleo del poder y de la prerrogativa como instrumentos de secularización y desamortización. No era infrecuente, por ejemplo, en España, advertir la locución servicio público para atribuir al Estado actividades excluidas de la desamortización. ${ }^{22}$

\section{Los servicios públicos económicos. La Concesión}

\footnotetext{
${ }^{16}$ Smith, Juan C., La autonomía de la voluntad y el contrato..., cit., pág. 40.

${ }^{17}$ La secularización de las fundaciones religiosas a raíz de la reforma protestante fue un antecedente de la asunción estatal de ciertos cometidos asistenciales.

${ }_{18}$ Muñoz Machado, Santiago, Servicio público y mercado, Madrid, Civitas, 1998, vol. I, Los fundamentos, 34, Ariño Ortiz, Gaspar, Economía y Estado, Buenos Aires, Abeledo-Perrot, 1993, pág. 348.

19 Santamaría Pastor, Principios..., vol. II, cit. pág. 302.

20 Garrido Falla, Fernando, Tratado de derecho administrativo, 8 a edic., Madrid, Tecnos, 1987, vol. II, pág. 268.

${ }^{21}$ Garrido Falla, Fernando, Tratado de derecho administrativo, cit., vol. II, pág. 268.
} 
Con el tiempo, los avances tecnológicos, las exigencias del industrialismo y las demandas comunitarias colocan al Estado ante la necesidad de asumir competencias prestacionales de naturaleza económica y de características complejas, las cuales, pese a no revestir, por tanto, carácter asistencial, requieren de él, sin embargo, una intervención justificada en la importancia comunitaria de su satisfacción, en la insuficiencia privada para hacerlo y en las notas de vocación monopolística que implicaban su desarrollo. $^{23}$

El servicio público se presenta, entonces, en esta etapa, como el título jurídico invocado por el Estado para asumir la titularidad de ciertas competencias prestacionales tales como, entre otras, las referidas al transporte ferroviario o por carretera, el correo, el telégrafo, la electricidad, el gas o el teléfono.

Es claro, sin embargo, que esta redefinición fáctica del accionar del Estado Liberal no podía producirse sin generar con ello una contradicción dialéctica insalvable con los propios presupuestos políticos que lo orientaban: incapacidad empresarial del Estado y abstención de éste en la vida económica.

La situación se salva, entonces, con la figura de la concesión traslativa, ${ }^{24}$ en virtud de la cual el Estado, después de autoatribuirse la titularidad de la actividad económica de que se trate, trasfiere su gestión o ejercicio a una persona privada que la asume por su cuenta y riesgo.

La concesión es, por eso, inherente a la explotación de los servicios públicos económicos en el Estado de Derecho Liberal y se erige en el modo más inteligente que éste halla para responde a las exigencias de los hechos a partir de una ideología que, si bien en sí misma repudiaba la actuación económica de aquél, debía dar cuenta, sin embargo, del propio desarrollo histórico del capitalismo liberal necesitado de un marco económico tecnológico que, por sí solo, éste no podía generar. ${ }^{25}$

$Y$ la prerrogativa va, ciertamente, unida, nuevamente, al servicio público; en este caso, como poderes jurídicos del concedente sobre el prestador e, incluso, como posibilitad de poderes de éste sobre el usuario, transferidas por aquél.

No es éste el momento para desarrollar en profundidad las mani-

\footnotetext{
22 Villar Ezcurra, José Luis, Servicio público y técnicas de conexión, Madrid, Centro de Estudios Constitucionales 1980, págs. 23 y 31

23 Ariño Ortiz, Gaspar, Economía y Estado, cit., pág. 339.

24 Zanobini, Guido, Curso de Derecho Administrativo, Buenos Aires, Arayú, 1954, vol. I, pág. 334.

${ }^{25}$ Kaplan, M., La empresa pública en los países capitalistas avanzados en "Crisis y futuro de la empresa pública, México, UNAM, 1994, pág. 39 y sigs., citado por Souvirón Morenilla, José María, La actividad de la administración y el servicio público, Granada, Comares, 1998, pág. 50, nota 88.
}

A \& C R. de Dir. Administrativo e Constitucional, Belo Horizonte, ano 4, n. 15, p. 79-106, jan./mar. 2004 
festaciones exorbitantes de la concesión; sólo cabe remitir para su estudio doctrinario a Escola ${ }^{26}$ y la lúcida exposición que resulta del fallo de la Cámara Nacional de Apelaciones en lo Contencioso Administrativo Federal, sala III, autos "Edenor c. Estado Nacional" (6.9.95), en el cual se advierte la pluma del Juez Coviello.

\section{Los poderes exorbitantes del servicio público como criterio de determinación de la jurisdicción contenciosa en Francia y como delimitación del Derecho Administrativo}

Es en Francia donde el servicio público, en tanto actividad regulada por un derecho exorbitante del privado, adquiere el carácter delimitador del Derecho Administrativo y, con ello, el criterio de determinación de la jurisdicción contencioso administrativa.

Es célebre, en ese sentido, el pronunciamiento del Tribunal de Conflictos en el caso "Blanco" 27 - extendido al ámbito local en el caso "Terrier" 28 - a tenor del cual las responsabilidades de los agentes estatales afectados al servicio público no pueden ser regidas por el derecho civil, resultando, por ende, necesario, regularla por reglas especiales que varían según las necesidades del servicio y de conciliar los intereses del Estado con los intereses privados. Se entronizaba, así, en Francia, un nuevo criterio para el Derecho Administrativo - el servicio público - y su autonomía respecto del Derecho Civil y, a partir de él, se define el alcance exclusivo de la jurisdicción administrativa a su respecto. ${ }^{29}$

El servicio público es, en definitiva, someter a reglas exorbitantes al Derecho Común el ejercicio de ciertas actividades; es la aplicación del Derecho Público a ciertos actos, sea en el marco de los organismos administrativos o fuera de ese cuadro orgánico. ${ }^{30}$

\section{La teorización del servicio público por la Escuela de Burdeos}

\section{y la prerrogativa}

Cuando a comienzos del siglo XX Duguit trata de cambiar el

\footnotetext{
${ }^{26}$ Escola, Héctor, Tratado integral de los contratos administrativos, Buenos Aires, Depalma, 1979, vol, II, pág. 68 y sigs.

${ }^{27}$ T. C. 8 févr. 1873, Blanco, Rec. ler. Supplt 61, concl. David públ. en Long, Marceau-Weil, Prosper-Braibant, Guy-Devolvé, Pierre-Genevois, Bruno, Les grands arrets de la jurisprudence administrative, Paris, Dalloz, $13 e$. édition, pág. 1 y sigs.

${ }^{28}$ CE 6 févr. 1903, Terrier, Rev. 94, concl. Romieu públ. en Long, Marceau-Weil, Prosper-Braibant, Guy - Devolvé, Pierre-Genevois, Bruno. Les grands arrets de la jurisprudence administrative, Paris, Dalloz, 13e. éditión, pág. 72 y sigs.

${ }^{29}$ Manzaneto, Mateos José, Servicios públicos: aproximación a su línea evolutiva en Estudios en Homenaje al profesor López Rodó, Madrid, Univ. de Santiago de Compostela - Univ. Complutense - Consejo Superior de Invest. Científicas, 1972, V. II, pág. 224.

${ }^{30}$ Manzanero, Mateos José, Servicios públicos..., en Estudios en Homenaje al profesor López Rodó, cit., pág.
}

A \& C R. de Dir. Administrativo e Constitucional, Belo Horizonte, ano 4, n. 15, p. 79-106, jan./mar. 2004 
fundamento legitimador del Estado, proponiendo la idea del servicio público como sustituta de la de soberanía, se hubiera podido, quizás, pensar que ese intento llevaba ínsita la eliminación de la prerrogativa exorbitante como una de las notas de aquel concepto.

No es así, sin embargo. De la propia noción del jurista francés se desprende que el poder sigue presente como nota tipificante del concepto, pues servicio público es la actividad, dice Duguit, cuyo cumplimiento debe ser regulado, asegurado y fiscalizado por los gobernantes, por ser indispensable a la realización y al desarrollo de la interdependencia social, y de tal naturaleza que no se puede realizar completamente mas que por la intervención de la fuerza gobernante $^{31}$ (subrayado me pertenece).

Y la nota publicística no es menor en Jéze, ${ }^{32}$ para quien decir que hay servicio público significa, en primer lugar, que, para dar satisfacción regular y continua a necesidades de interés general pueden los agentes públicos aplicar los procedimientos de derecho público, es decir, utilizar un régimen jurídico especial y, en segundo, que la organización del servicio público puede ser modificada en todo instante por las leyes y reglamentos.

Hauriou, por su lado, el célebre contradictor de la Escuela de Burdeos, señala como datos esenciales del régimen francés al servicio público y al poder; el primero como obra a realizar por la Administración; el segundo como medio de realización. ${ }^{33}$ El poder como instrumento del servicio halla en éste la idea objetiva que le permite autolimitarse. La fuerza del hecho del poder, propio del realismo de la Escuela, se juridiza con el servicio público.

Los constructores más típicos del concepto vienen, pues, a coincidir, más allá de sus discrepancias, en la consideración del servicio público como un título de actuación ligado al poder servicial.

Esta idea es la que también da fundamento al concepto en la doctrina española, en la cual se ha hecho clásica la consideración del servicio público como actividad publificada por el Estado ${ }^{34}$ y excluída, por tanto, de la actividad privada sin previa concesión..$^{35}$

\section{El ocaso de la concesión. La asunción directa de las actividades económicas. La primera crisis de la noción de servicio público}

El ocaso de la concesión por la inviabilidad de su explotación

${ }^{31}$ Duguit, León, Las transformaciones del Derecho Público, Madrid, F. Beltrán, 1926, 2da. edic., pág. 105.

32 Jéze, Gastón, Principios generales del Derecho administrativo, Buenos Aires, Depalma, 1949, t., II, pág. 4 y sigs.

${ }^{33}$ Hauriou, Maurice, Obra escogida, Madrid, Inst. de estudios administrativos, 1976, pág. 117.

34 Acto de publicatio según la célebre expresión de Villar Palasí, (Mairal, La ideología..., cit., nota 71).

${ }^{35}$ Ariño, Economía..., cit., pág. 349.

A \& C R. de Dir. Administrativo e Constitucional, Belo Horizonte, ano 4, n. 15, p. 79-106, jan./mar. 2004 
lucrativa, ${ }^{36}$ la consideración de ciertas actividades como estratégicas a raíz de la experiencia de la Primera Guerra Mundial, ${ }^{37}$ la implementación de políticas industrialistas en estados descapitalizados, ${ }^{38}$ la influencia cierta de las ideas socialistas, ${ }^{39}$ fueron, todos, factores ${ }^{40}$ que influyeron para que el Estado asumiera, progresivamente, la prestación directa de servicios hasta entonces en manos de concesionarios (nacionalizaciones y municipalizaciones del primer tercio del siglo XX) y, especialmente, para que después de la Segunda Guerra Mundial se generalizara nacionalizaciones mediante - la actuación empresarial del Estado en el ámbito prestacional industrial y comercial. ${ }^{41}$

Con esta última actuación se generaliza y revitaliza, pues, la idea del servicio público industrial y comercial, definida ya por el Tribunal de Conflictos en el arret "Eloka" 42 como servicio explotado por el Estado en las mismas condiciones del "industrial ordinario".

La "empresa pública" que de esa forma se desarrolla origina, entonces, la cuestión relativa a su compatibilización con la idea del servicio público, habida cuenta de la sumisión de aquélla al marco, en principio, dominante del derecho privado.

Como recuerda Villar Ezcurra, hay una ley sociológica muy curiosa que determina que la vida jurídica se desarrolle no siempre a cielo abierto, lo cual, en el caso del servicio público, conduce a la mutabilidad de las técnicas habilitantes de potestades. ${ }^{43}$ Por eso, si bien los servicios públicos industriales y comerciales están sometidos al derecho privado, ello no deja de ser, en rigor, como ha puntualiza Weil, ${ }^{44}$ una presunción contradicha por la comparación acto a acto. Así, los bienes afectados pueden ser del dominio público; las obras que les conciernen pueden asumir la calidad de públicas; la responsabilidad frente a terceros puede estar disciplinada por el derecho público; incluso sus decisiones pueden ser actos administrativos. ${ }^{45}$

\footnotetext{
${ }^{36}$ El caso de los ferrocarriles (Souvirón Morenilla, José María, La actividad de la administración..., cit. pág. 52.

37 Santamaría Pastor, Principios..., cit., t. II, pág. 304.

38 Santamaría Pastor, Principios..., cit., t. II, pág. 304.

39 Santamaría Pastor, Principios..., cit., t. II, pág. 305

40 Respecto de la influencia de la doctrina social de la Iglesia, véase Langlois Ibáñez, José Miguel, Doctrina social de la Iglesia, Ediciones Universidad Católica de Chile, 1988, pág. 189.

${ }^{41}$ Souvirón, La actividad..., cit., págs. 52/53.

42 (TC. 22 janv. 1921, Société Commerciale de L'Ouest Africain, Rec. 91, en Long, Marceau; Weil, Prosper; Braibant, Guy; Devolvé, Pierre; Genevois, Bruno, Les grands arrets de la jurisprudence administrative, Paris, Dalloz, 13e. édition, pág. 228 y sigs.) A partir de esta decisión bac d'Eloka, comienza a hablarse de services publics industriels ou commerciaux" como opuestos a los "services publics administratifs" o "services publics proprement dits, Muñoz Machado, Santiago, Servicio Público..., ob. cit., pág. 88.

43 Villar Ezcurra, Servicio público..., cit., págs. 24/25.

${ }^{44}$ Weil, Prosper, Derecho administrativo, Madrid, Civitas, 1986, pág. 117.
} 
Esta descripción del jurista francés hace recordar, por cierto, nuestra propia situación durante el apogeo de la actividad empresarial del Estado. ¿O acaso no se discutió entre nosotros la calidad de los bienes de las empresas; la condición de sus obras; el status de sus agentes o la naturaleza de sus actos?

Y es natural que ello sea así, porque como ha señalado Fernández, ${ }^{46}$ una cosa es que la Administración utilice la forma de sociedad anónima y otra, muy distinta, que por este solo hecho pueda disponer de la autonomía de la voluntad propia de los particulares. La Administración Pública es siempre un poder público, con todo lo que ello significa de prerrogativa y garantía.

Los servicios públicos industriales y comerciales vienen también a evidenciar la fuerza subyacente de un título de actuación administrativa que, con apoyo en la realidad de las cosas, perfora el velo privatístico de una actividad que más allá de su naturaleza industrial o comercial, no puede, en razón de su fin público, reconocer en el derecho privado un cauce regulador excluyente de la prerrogativa.

\section{El repliegue empresarial de Estado y la ola privatizadora. Una nueva crisis del concepto servicio público, de signo inverso}

A partir aproximadamente de los años 80 se ha producido en todo el mundo, tanto europeo como iberoamericano, una ola privatizadora.

No es este el momento de estudiar las razones que originan este movimiento global, ni tampoco los instrumentos técnicos utilizados para su concreción. Sólo cabe señalar, en el primer aspecto, la incidencia de indudables motivaciones ideológicas reivindicatorias del ideario liberal, junto a la gravitación de requerimientos que no exceden en su génesis el pragmatismo gubernamental; y, en el segundo, simplemente recordar que el traspaso involucrado en la privatización puede importar, como antes dije, desde la venta de bienes estatales a los particulares, a la transferencia de actividades o servicios y, en este segundo supuesto, reteniendo la publicatio o bien trasladando tanto la titularidad como la gestión de la actividad. ${ }^{47}$

Así como la expansión de la actividad del Estado determinó, en su momento, la primera crisis del servicio público en tanto éste pareció diluirse como título exorbitante al aparecer la prestación estatal sometida al régimen jurídico privado;

\footnotetext{
45 Weil, Prosper, Derecho administrativo, cit., pág. 117

${ }^{46}$ Fernández, Tomás Ramón, Panorama del derecho administrativo al comienzo de su tercera centuria, Buenos Aires, La Ley, pág. 62.

${ }^{47}$ Ariño, Economía..., cit., pág. 294.
}

A \& C R. de Dir. Administrativo e Constitucional, Belo Horizonte, ano 4, n. 15, p. 79-106, jan./mar. 2004 
ahora, con el repliegue empresarial del Estado se asiste, de algún modo, a una crisis de signo inverso porque ella deriva, precisamente, de un retiro estatal del ámbito comercial o industrial, no acompañado, sin embargo, de un abandono del empleo del título jurídico servicio público.

El concepto no desaparece, pero no se identifica con el tradicional (monopólico, igualitario, uniforme); la realidad de la integración europea en su contenido de libertades de comercio de productos y mercancías, de circulación de capitales y trabajadores y de establecimiento y prestación de servicios en el marco de la Comunidad es, en ese sentido, un factor esencial. $^{48}$

La desconsideración inicial de la comunidad europea por el servicio público en su concepción francesa fue, no obstante, cediendo a las exigencias virtuales de índole exorbitante del servicio público. Primero, porque la ideología de la mayor parte de los Estados europeos no se resigna a perder un Estado ocupado de la solidaridad y bienestar de los ciudadanos. Debo expresar, en este aspecto, mi admiración por esta lealtad moral de la vieja Europa, a los valores superiores de la solidaridad y la justicia social. Y, segundo, porque la apertura de la competencia y la incorporación de entidades privadas al área liberalizada, se ha acompañado de la imposición de obligaciones mínimas inherentes a las prestaciones que se enmarcan en el concepto del servicio universal, muy vecino al de servicio público tradicional. ${ }^{49}$

La regla comunitaria que impone el sometimiento a las reglas de la competencia de las empresas encargadas de la gestión de servicios de interés económico general o que tengan el carácter de monopolio fiscal, rige, por lo demás, siempre que la aplicación de esas reglas no impida, de hecho o de derecho, el cumplimiento de las misiones específicas que ellas tengan asignadas (artículo $90 \mathrm{del}$ Tratado de la CE). ${ }^{50}$ Como se advierte, aunque como excepción, la prerrogativa sigue existiendo.

\section{La situación en nuestro país}

La Constitución de 1853-60

La Constitución histórica 1853-60 reconoce y garantiza, en su art. 14 , entre otros derechos fundamentales, los de trabajar, comerciar y ejercer

\footnotetext{
${ }^{48}$ Ariño Ortiz, Gaspar, La regulación económica, Ábaco de Rodolfo Depalma, Buenos Aires, 1996, pág. 59.

${ }^{49}$ Muñoz Machado, Servicio público y mercado..., cit., t. 1, pág. 35.

${ }^{50}$ Ver, Muñoz Machado, Servicio público y mercado..., cit., t. 1, págs. 36/8.
}

A \& C R. de Dir. Administrativo e Constitucional, Belo Horizonte, ano 4, n. 15, p. 79-106, jan./mar. 2004 
toda industria lícita, conforme con las leyes que reglamenten su ejercicio. Es ésta una definición filosófica que coloca, en principio, la titularidad de la actividad comercial e industrial en el ámbito privado.

La justa y armoniosa articulación que ese texto fundamental consagra entre los derechos individuales y las exigencias del interés público (el bienestar general invocado en el Preámbulo) se torna evidente cuando se advierte que, paralelamente, en el art. 67, inc. 16, (en su antigua redacción) de la parte orgánica, la constitución ya consagra la denominada cláusula de la prosperidad o del progreso que incluye la posibilidad de otorgar concesiones temporales de privilegios - monopolios e exclusividades ${ }^{51}-\mathrm{y}$ recompensas de estímulo. ${ }^{52}$

No es posible, entonces, sostener que la Constitución era neutral respecto de la posibilidad de declarar servicio público una determinada actividad comercial o industrial, si, con ello, se quería significar que el Estado asumía la titularidad de esa actividad y que, por tanto, su realización por los particulares sólo podía resultar, en ese caso, de una concesión de éste.

El principio en la Constitución era, a mi juicio, la titularidad privada de esas actividades mientras la titularidad pública era, en cambio, la excepción, sólo justificable por exigencias del interés público, las que, al menos inicialmente, se consideraron configuradas, únicamente, respecto del servicio de correos y obras sanitarias..$^{53}$

\section{La figura de la concesión}

Ahora bien, la concepción instrumental de la Constitución - en el sentido de medio de gestión de la prosperidad pública ${ }^{54}$ - permitió, sin embargo, que sin contradecir su filosofía inspiradora se utilizara la concesión como modo de procurar la prosperidad mediante el desarrollo de ciertas actividades industriales y comerciales.

El Estado, del mismo modo que había ocurrido en Europa, asume la decisión de titularizar actividades en las que considera comprometido el interés general, y, por cierto, el propio desarrollo del sistema capitalista, pero

\footnotetext{
${ }^{51}$ Marienhoff distingue entre monopolio y exclusividad. El primero implica que una actividad se sustrae de la concurrencia y se reserva para su desarrollo sólo por una persona pública o privada. La segunda significa que el Estado asegura a quien es objeto de ella que no otorgará nuevas concesiones para el mismo servicio o actividad. (Los privilegios en el derecho público. (exclusividad; monopolio; exención impositiva) Lo atinente a la "reserva de zona". La "zona de influencia". ReDA, n 17, pág. 327 y sigs. esp. pág. 334).

52 Marienhoff, Los privilegios en el derecho público..., cit., pág. 332.

53 Mairal, La ideología..., cit., pág. 385.

${ }^{54}$ Oyhanarte, Poder político..., pág. 16.
}

A \& C R. de Dir. Administrativo e Constitucional, Belo Horizonte, ano 4, n. 15, p. 79-106, jan./mar. 2004 
las concede a los privados, en tanto, en el marco de aquella filosofía, es a éstos a quienes les corresponde, en principio, cumplirlas (v. gr.: concesiones ferroviarias; de electricidad, gas, transvías, etc.).

Como se ve, el servicio público opera como título exorbitante para la exclusión de la titularidad privada de la actividad.

La doctrina argentina influenciada por la francesa y la jurisprudencia de la Corte Suprema daba, por lo demás, sustento teórico a la técnica concesional, siendo ilustrativas, en ese sentido, las definiciones plasmadas en la Cuarta Conferencia Nacional de Abogados de 1936.

\section{El cambio operado por la Constitución de 1949}

Un cambio significativo se produce con la sanción de la Constitución justicialista de 1949 — dejada sin efecto en el año 1956 - en cuyo artículo 40 se decide, por un lado, la pertinencia originaria de los servicios públicos al Estado y la prohibición terminante de su enajenación o concesión, y, por otro, las transferencias a aquél de los que estuvieren en poder de los particulares, mediante compra de expropiación con indemnización previa cuando una ley lo determinara.

El servicio público, otra vez, como título exorbitante: en este caso, para consagrar no sólo la titularidad pública de ellos, sino, incluso, para prohibir su enajenación o concesión. Fue la época de las nacionalizaciones.

\section{La situación en la década del 90}

Así es como se llega a la década del 90, en la cual el Estado se presenta como prestador directo, bajo diversas formas jurídicas (empresas del Estado; sociedades del Estado; sociedades anónimas con participación estatal mayoritaria; entidades descentralizadas atípicas) de actividades también distintas: correos y telégrafos; teléfonos; transporte y distribución de gas; generación, transporte y distribución de electricidad; obras sanitarias; transporte aéreo de cabotaje y transporte ferroviario. ${ }^{55}$

Directa o indirectamente el servicio público, invocado, en su momento, como sustento para la nacionalización, gravitaba con ultraactividad como título para el monopolio estatal.

Experiencias frustradas por diversas razones (v.gr. decreto 1842/87 y antes, incluso, la ley 22.177 de 1980, durante el gobierno de facto) fueron seguidas en 1989 por la sanción de la ley 23.696, denominada de reforma

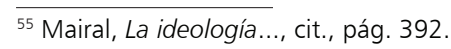

A \& C R. de Dir. Administrativo e Constitucional, Belo Horizonte, ano 4, n. 15, p. 79-106, jan./mar. 2004 
del Estado, en virtud de cuyo art. $1^{\circ}$ se declaró en emergencia la prestación de los servicios públicos y la situación económico financiera de la administración pública nacional, y se facultó, asimismo, al Poder Ejecutivo, para otorgar permisos, licencias o concesiones para la explotación de los servicios públicos o de interés público a que estuvieren afectados los activos, empresas o establecimientos que se privatizaran, consignándose, en dos anexos, las empresas y activos "sujetas a privatización".

¿Cómo habrá de operar, entonces, a partir de ese momento, el concepto de servicio público?

La respuesta no se puede proporcionar sólo en el marco de la ley referida, porque después de ella, en el año 1994, se reformó la Constitución y, en ésta, aparece por primera vez en ese primer plano normativo la locución servicio público. La respuesta que derive de la Constitución deberá incluso operar sobre privatizaciones realizadas con anterioridad, el supuesto de que éstas consagren un régimen diverso del plasmado por la Constitución.

\section{La reforma constitucional de 1994}

La Constitución reformada se refiere expresamente a los servicios públicos, en el segundo párrafo del artículo 42, para imponer a las autoridades el deber de proveer al control de la calidad y eficiencia de ellos; y después, en el párrafo tercero del mismo artículo, para determinar que la legislación debe establecer los marcos regulatorios de los servicios públicos de competencia nacional, previendo la necesaria participación de las asociaciones de consumidores y usuarios y de las provincias interesadas, en los organismos de control.

Es indudable, asimismo, que se refieren también a los servicios públicos las previsiones del artículo citado que, por un lado, reconocen a los usuarios, en la relación de consumo, el derecho a la protección de la salud, seguridad e intereses económicos; a una información adecuada y veraz; a la libertad de elección y a condiciones de trato equitativo y digno; e imponen, por otro, a las autoridades el deber de proveer a la protección de esos derechos, a la educación para el consumo; a la defensa de la competencia contra toda forma de distorsión de los mercados; al control de los monopolios naturales y legales y a la constitución de asociaciones de consumidores y usuarios.

\section{El sistema de los servicios públicos en la reforma de 1994}

De la cláusula en comentario es posible desprender la instrumentación constitucional de un sistema de servicios públicos, montado sobre las dos
A\& C R. de Dir. Administrativo e Constitucional, Belo Hortzonte, ano 4, n. 15, p. 79-106, jan./mar. 2004 
siguientes ideas:

a) el reconocimiento y protección de los derechos de los usuarios de los servicios públicos; y

b) la consagración de un plexo de potestades estatales orientadas, primordialmente, al control y la regulación, cuyo sentido radica en la protección de tales derechos.

El fin del sistema es, pues, la protección de los derechos pero la potestad es el medio que los asegura. El poder al servicio de la libertad. $Y$ otra vez el servicio público como título jurídico para la prerrogativa servicial.

\section{¿Titularidad, asunción subsidiaria o Policía?}

Así las cosas, cabe, entonces, preguntar si las potestades estatales de control y regulación que la norma constitucional consagra, reconocen como supuesto implícito la titularidad estatal de la actividad prestadora del servicio; si ellas son derivaciones del título jurídico servicio público para, a partir de él, habilitar el ejercicio del pertinente poder de policía (que no otra cosa es la regulación y el control); si comprende ambas alternativas o si, en su caso, abarca la posibilidad de la asunción subsidiaria de la actividad.

Una conclusión válida supone, por lo demás, la necesidad de interpretar los criterios plasmados en el art. 42 de modo coherente con previsiones constitucionales tuitivas de derechos que también están en juego a la hora de construir un sistema de servicios públicos (v.gr.: trabajar, comerciar, ejercer industria lícita); sin descuidar tampoco, y paralelamente, otras normas constitucionales atributivas de potestades generales para la búsqueda de la prosperidad general, como son, por ejemplo, las que se prevén en el artículo 75, inciso 19 (proveer lo conducente al desarrollo humano, al progreso económico con justicia social, a la productividad de la economía, entre otras).

La reforma de 1994 hace explícitos criterios de intervención estatal que hasta ese momento sólo resultaban de decisiones legislativas y pronunciamientos jurisprudenciales concebidos al amparo de un método dinámico y, en ocasiones, mutante de interpretación constitucional. ${ }^{56}$

A mi juicio no es dudoso, en ese sentido, que se buscó configurar un Estado garante del desarrollo humano, el crecimiento económico y la Justicia Social y, por ende, conformador de la realidad social en ese marco teleológico. Los ya referidos artículos 42 y 75, inciso 19, son, en ese aspecto, elocuentemente reveladores.

Esa finalidad no pudo, sin embargo, ser procurada alterando, en ${ }^{56}$ Oyhanarte, Poder político..., cit., pág. 20.

A \& C R. de Dir. Administrativo e Constitucional, Belo Horizonte, ano 4, n. 15, p. 79-106, jan./mar. 2004 
modo alguno, las declaraciones, derechos y garantías contenidos en el capítulo único de la Primera Parte de la Constitución. El art. $7^{\circ}$ de la ley 24.309, declaratoria de la necesidad de la reforma constitucional prohibió, expresamente, cualquier cambio en esa materia.

Si ello es así, corresponde, entonces, considerar que las conclusiones sentadas en el marco de la Constitución 1853-60 siguen siendo, en este aspecto, válidas, es decir que, aún después de la reforma de 1994, el desarrollo de las actividades comerciales e industriales pertenece, en principio, a la esfera de actuación de los particulares.

Esa conclusión no obsta, en modo alguno, a que, por otro lado, sea afirmada la presencia del control y regulación del Estado lo cual no supone, ciertamente, la necesaria asunción por éste de la actividad de que se trate. La letra del propio art. 42 confirma esta idea, en tanto se refiere al control de la calidad y eficiencia de los servicios públicos y a la sanción de la legislación que contemple los marcos regulatorios de tales servicios. $\mathrm{Ni}$ para controlar, ni para regular es necesario ser dueño.

El principio en la Constitución, es, pues, el control y la regulación, es decir, el poder de policía; aun cuando ello no obste para que, de todos modos, el legislador siga gozando de la posibilidad excepcional de conceder, por razones debidamente fundadas de bien común - con publicatio o sin ella - privilegios temporales - por vía de monopolio o exclusividad ${ }^{57}$

La publicatio es, pues, una alternativa excepcional pero viable, toda vez que ella es derivable como poder inherente a la idea conformadora y positiva del Estado que traducen los arts. 42 y 75, incisos 18 y 19 de la Constitución. Y lo mismo ocurre con la posibilidad de asumir una actividad, sin titularizarla, cuando no haya particulares idóneos para prestarla. Publicatio propia y Publicatio impropia, respectivamente, darían, así, cuenta terminológica de ambas situaciones.

En el marco de la Constitución es posible, entonces, concluir en que el servicio público importa un título jurídico para el control y la regulación de las actividades que merezcan esa calificación, esto es, para su sometimiento al poder de policía, lo cual no supone, necesariamente, la publicatio de la actividad, aun cuando ni ella ni la publicatio impropia son descartables como alternativas excepcionales fundadas en los poderes inherentes al Estado Garante-Conformador diseñado por la Constitución.

Ahora bien, a los efectos de este estudio tomaré los marcos

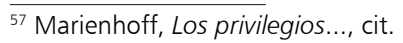

A \& C R. de Dir. Administrativo e Constitucional, Belo Horizonte, ano 4, n. 15, p. 79-106, jan./mar. 2004 
regulatorios de cuatro actividades esenciales para determinar cuáles son, en ellos, los alcances que adquiere la caracterización como servicio público de tales actividades. Me refiero a los servicios de abastecimiento de agua potable y servicios cloacales; transporte y distribución de energía eléctrica; transporte y distribución de gas natural y telecomunicaciones.

\section{El Servicio Público en cuatro marcos regulatorios}

Así, pues, el decreto 999/92 consigna que el servicio público regulado por él se define como la captación y potabilización, transporte, distribución, disposición y comercialización del agua potable; la colección, tratamiento, disposición y comercialización de desagües cloacales, incluyéndose los efluentes industriales que el régimen vigente permita se viertan al sistema cloacal $^{58}$ y la ley 24.065 caracteriza como servicio público al transporte y distribución de electricidad. ${ }^{59}$ Por su lado, la ley 24.076 determina que el transporte y distribución de gas natural constituyen un servicio público nacional, ${ }^{60}$ mientras que la prestación del servicio de telecomunicaciones había sido ya considerada un servicio público por el decreto 62/90 cuando se convocó a un concurso público internacional para la privatización de la prestación. ${ }^{61}$

Es de suponer que el legislador ha considerado que la caracterización como servicio público de las actividades enunciadas constituía un medio idóneo para el logro de los objetivos fijados a la regulación en cada uno de los marcos.

\section{Las consecuencias jurídicas de la caracterización ¿Régimen jurídico unitario? Pautas para su posible determinación}

Cabe, entonces, preguntar cuáles son las consecuencias derivadas de tales caracterizaciones legales: concretamente ¿qué significa, jurídicamente, categorizar a una actividad como servicio público? ¿Se puede hablar de un régimen jurídico unitario del servicio público, al menos en el ámbito de estos marcos regulatorios?

Plantear un régimen unitario no importa, desde luego, ignorar que

\footnotetext{
${ }_{58}$ Art. 10, Anexo l, decreto 999/92 - marco regulatorio para la concesión de los servicios de provisión de agua potable y desagües cloacales-

${ }^{59}$ Art. $1^{\circ}$, ley 24.065: art. $1^{\circ}$, decreto regl. 1398/92.

60 Art. $1^{\circ}$, ley 24.076.

${ }^{61}$ En la todavía vigente ley de telecomunicaciones 19.798 , se hace referencia al servicio público de telecomunicaciones, (por ej. en el art. 25; art. 39; art. 40; art. 41, entre otros); art. 10, también en el Anexo I, Capítulo VII, pto. 7.1.1.; Capítulo VIII, pto. 8.5; Capítulo X, pto. 10.1.2; 10.1.4; Capítulo XIII, pto. 13.2. del decreto 62/90; finalmente el art. $8^{\circ}$ del decreto 1185/90.
} 
cada una de las actividades posee, en razón de sus especificidades técnicas, comerciales y financieras, exigencias regulatorias propias y adaptadas adecuadamente a tales singularidades.

El interrogante apunta, en rigor, a ciertos aspectos que son esenciales para definir el régimen jurídico, los cuales, a mi juicio, se podrían resumir en los cinco siguientes:

a) título de acceso a la actividad;

b) duración de la habilitación;

c) existencia, o no, de publicatio de la actividad;

d) existencia, o no, de rescate; y

e) régimen de los bienes (trasferencia de los activos públicos al prestador, en propiedad o en simple tenencia; reversión, o no, al finalizar la habilitación y, en su caso, condiciones).

\section{a) El título de acceso a la actividad}

No existe un criterio claro que permita diferenciar con precisión las figuras de la concesión y de la licencia. ${ }^{62}$

Por mi parte, me inclino a compartir la idea que, en el ámbito de los servicios públicos remite la primera, en lo esencial, al acto de trasladar a un particular el ejercicio de competencias o facultades propias del Estado, atribuyendo, así, a aquél, un poder nuevo, pero derivado de la titularidad de éste; ello, sin perjuicio de la admisión de la concesión constitutiva, en tanto acto de atribución al particular de un poder, también nuevo, pero no derivado de la titularidad estatal. El concepto de licencia, por su lado, parece conveniente referirlo al acto de remoción de obstáculos al ejercicio de poderes preexistentes, lo cual, aplicado al servicio público, importa suponer la titularidad privada de la actividad a desarrollar por el licenciatario. Es la perspectiva que deriva, como ha señalado Tawil, del derecho francés y norteamericano, respectivamente. ${ }^{63}$

Ahora bien, en lo que se refiere al ingreso a la actividad, cabe señalar que los regímenes regulatorios del servicio de abastecimiento de agua potable y servicios cloacales ${ }^{64}$ y de transporte y distribución de

\footnotetext{
62 Tawil, Guido, A propósito del proyecto de ley de concesiones, licencias y permisos de servicios públicos nacionales y figuras vecinas, Rap. No 252, pág. 18 y sigs.; para Marienhoff, la licencia es una figura jurídica híbrida, ambigua, de contornos imprecisos, que fluctúa entre la concesión y el permiso, acercándose más al permiso. Los privilegios..., cit., pto. V.

${ }^{63}$ Tawil, Guido, A propósito del proyecto de ley de concesiones..., cit., Rap. № 252, pág. 20.

${ }^{64}$ Art. $7^{\circ}$, Anexo I, decreto 999/92.

${ }^{65}$ Art. $3^{\circ}$, ley 24.065 .
}

A \& C R. de Dir. Administrativo e Constitucional, Belo Horizonte, ano 4, n. 15, p. 79-106, jan./mar. 2004 
energía eléctrica ${ }^{65}$ contemplan a la concesión; mientras que, en cambio, los relativos a la prestación del servicio de telecomunicaciones ${ }^{66}$ y del transporte y distribución de gas natural ${ }^{67}$ a la licencia.

Además de esa diferencia corresponde puntualizar que los contenidos jurídicos de la concesión y de la licencia son también diversos. Como se verá seguidamente al considerar la duración, la publicatio, el rescate y el régimen de bienes, la concesión en el agua no tiene la misma significación que la concesión en el transporte y distribución de energía eléctrica; y la licencia en las telecomunicaciones no tiene el mismo alcance que la licencia en el gas.

\section{b) La duración de la habilitación}

La concesión en aguas esta otorgada por 30 años, ${ }^{68}$ y las concesiones eléctricas ${ }^{69}$ por 95 años, prorrogables por un plazo máximo de 10 años.

La licencia en materia de telecomunicaciones carece de límites temporales, ${ }^{70}$ salvo en lo que se refería a la exclusividad; mientras que las del gas ${ }^{71}$ duran 35 años, con opción a una única prórroga de 10 años.

\section{c) La publicatio}

La publicatio está presente en el régimen del agua, como se desprende de la expresa consideración del rescate en el marco regulatorio y de la transferencia de los activos al concesionario en calidad de simple tenencia. $^{72}$

No aparece, en cambio, y, por el contrario, se desprende su exclusión en el caso de las concesiones para el transporte y distribución de energía eléctrica, en la medida en que estas actividades deben ser desarrolladas, prioritariamente, por personas jurídicas privadas, ${ }^{73}$ siendo de destacar, incluso, que, según dispone el decreto reglamentario es responsabilidad de la Secretaria de Energía y del Ente Regulador asegurar que las actividades permanezcan a cargo del sector privado. ${ }^{74}$ La exclusión de la publicatio se refuerza, asimismo, con la trasferencia en propiedad de los bienes al

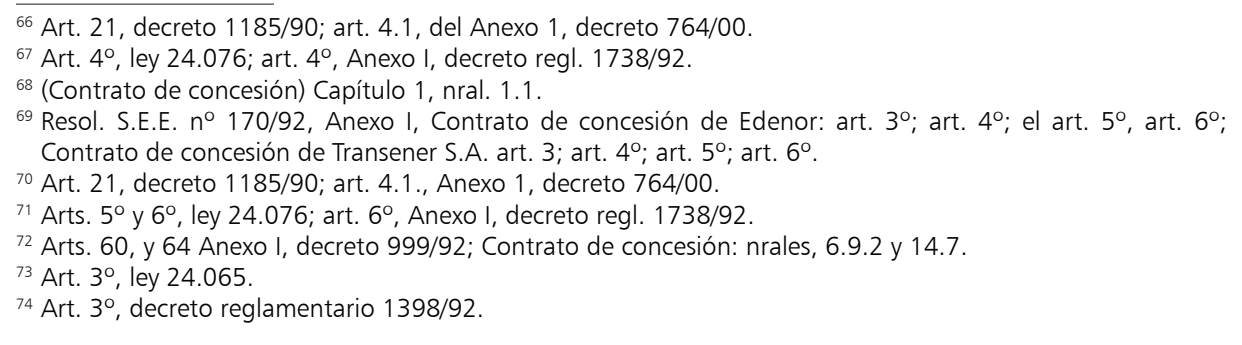

A \& C R. de Dir. Administrativo e Constitucional, Belo Horizonte, ano 4, n. 15, p. 79-106, jan./mar. 2004 
concesionario (ver infra texto y nota 84).

La concesión a los particulares, a diferencia de lo que sucede en el régimen del agua, es, pues, en estos casos, constitutiva en el sentido de que no traslada al privado una actividad propia del Estado que éste puede reasumir cuando lo estima conveniente u oportuno; simplemente se constituye en aquél un poder nuevo que no es derivación de otro preexistente en cabeza del Estado.

En estas actividades el Estado sólo puede asumir la prestación, con el fin de garantizar la continuidad del servicio, cuando, cumplidos los procedimientos de selección pertinentes, no hayan existido oferentes a quienes adjudicar la prestación de aquél. ${ }^{75}$ Se trataría de una publicatio que se podría denominar impropia, en atención a su carácter subsidiario.

La reglamentación legislativa es razonable, porque se bien limita la posibilidad de asunción de la actividad a través de una clara política privatizadora que excluye, como principio, la prestación estatal, no vacía a la función administrativa, titularizada por el Poder Ejecutivo, de la potestad inherente de asumir la actividad cuando ésta no pueda ser atendida convenientemente por los particulares.

La publicatio no aparece tampoco en las licencias de transporte y distribución del gas, ni en las correspondientes a los servicios de telecomunicaciones. En el primer caso la conclusión deviene, por un lado, porque el Estado y, en su caso, las provincias sólo pueden proveer servicios de transporte y distribución de gas cuando fracasaren los procedimientos de selección de oferentes o se extinguiere la habilitación ${ }^{76}$ y se diera la misma situación, supuestos; éstos, que generan, al igual que en las concesiones eléctricas, un caso que hemos dado en llamar de publicatio impropia; por otra parte, la conclusión se refuerza, además, por la transferencia de los bienes en propiedad al licenciatario. En el segundo la ausencia de publicatio resulta de la inexistencia de plazo para la licencia y de la transmisión en propiedad de los bienes al licenciatario. ${ }^{77}$

d) Existencia, o no, de rescate. La revocación por oportunidad

El rescate, aplicado a los servicios públicos, es el acto por el cual

\footnotetext{
${ }^{75}$ Art. 30, ley 24.065.

${ }^{76}$ Art. 40, ley 24.076; art. 40. Anexo I, decreto regl. 1738/92.

77 Decreto 62/90, Anexo I, Pliego de bases y condiciones para el concurso público internacional para la privatización de la prestación del servicios de telecomunicaciones: Capítulo VII, pto. 7.2.; Capítulo VII, pto. 7.2 .2
}

A \& C R. de Dir. Administrativo e Constitucional, Belo Horizonte, ano 4, n. 15, p. 79-106, jan./mar. 2004 
el Estado concedente de la explotación del servicio, decide, por razones de oportunidad, mérito o conveniencia, extinguir la concesión y asumir la prestación directa del servicio. La revocación por razones de oportunidad, mérito o conveniencia es también un acto que coincide en su fundamento con el rescate - mérito, oportunidad, o conveniencia - pero difiere de él en que, con ella, el Estado no reasume la prestación de la actividad sino que, lisa y llanamente, pone fin al contrato.

El rescate está previsto, expresamente, en el régimen del agua, ${ }^{78}$ aun cuando en su definición es confundido con la revocación por razones de oportunidad, mérito o conveniencia, pues se lo considera como la declaración unilateral, del concedente, adoptada por fundadas razones de interés público, por la cual se da por terminada la concesión. Cabe pensar que se ha estimado que, implícitamente, la conclusión de la concesión tanto puede conducir a la reasunción o bien a una nueva concesión. Por eso, entiendo que el rescate, tal como aparece definido, comprendería al rescate propiamente dicho y también a la revocación por razones de interés público.

Las concesiones eléctricas, por su parte, no contemplan expresamente ni a uno, ni a otra. De todos modos, es posible que en estos casos se configure una situación en cierto modo equivalente al rescate; una especie, podríamos afirmar, de rescate "impropio", correlativo de la ya apuntada publicatio impropia.

Ello es así, en efecto, por lo siguiente. De acuerdo con el régimen legal el Estado sólo puede asumir la prestación del servicio cuando, sustanciados los correspondientes procedimientos de selección, no existan oferentes privados adecuados para su adjudicación. ${ }^{79} \mathrm{La}$ inexistencia de oferentes aprehendida por la ley puede derivar, a mi juicio, de la ausencia de ofertas o de la inadmisibilidad o inconveniencia de éstas. Es claro, entonces, que, en los tres casos, el Estado puede optar por asumir la actividad si no decide reformular las condiciones planteadas para la selección.

Se trataría, pues, no de una reasunción o rescate, sino directamente, de una asunción nueva y subsidiaria a la privatización (publicatio impropia, traducida en un rescate impropio), originada en una valoración de mérito, oportunidad o conveniencia, que excluye, necesariamente, la indiferencia estatal frente al vacío servicial y que determina consecuentemente, la

\footnotetext{
${ }_{78}$ Contrato de concesión: nral. 14.7

${ }^{79}$ Art. $3^{\circ}$, ley 24.065 .
}

A \& C R. de Dir. Administrativo e Constitucional, Belo Horizonte, ano 4, n. 15, p. 79-106, jan./mar. 2004 
correlativa obligación, también estatal, en ese caso, de llenarlo. Es una manifestación del Estado garante-conformador diseñado por la Constitución.

La revocación por oportunidad no está tampoco prevista, como dije; sin embargo ella procede, genéricamente como atributo de la función administrativa, reconocido además, legislativamente, por el artículo 18 de la LNPA.

En el supuesto de las licencias para el transporte y distribución de gas natural, el decreto reglamentario de la ley 24.075 determina que el rescate sólo es posible con el acuerdo del licenciatario. ${ }^{80}$ Esta norma es, en mi opinión, inconstitucional, en tanto importa una renuncia por el Poder Ejecutivo a una potestad de gestión que es inherente a la titularidad de la función administrativa propia del Estado contemplado por la Constitución.

Si el Estado, del mismo modo que sucede con las concesiones eléctricas, asume la prestación del servicio cuando no existen privados adecuados, ${ }^{81}$ no es coherente que por vía reglamentaria, se autoexcluya, genéricamente, de la posibilidad de acudir al rescate, al menos impropio. Esta renuncia afecta, pues, la concepción constitucional del Estado y también la interpretación que, como derivación de él, instrumenta el marco legal.

Por ello, estimo que las conclusiones vertidas respecto de las concesiones eléctricas son igualmente aplicables a las licencias para el transporte y distribución del gas, y que, por ende, en estas actividades es también posible acudir al rescate impropio tal como antes lo indicamos.

Por la misma razón expuesta respecto de las concesiones eléctricas, entiendo que también procede en este caso la revocación por razones de oportunidad, mérito o conveniencia.

Las licencias telefónicas, por su parte, tampoco contemplan el rescate. De todos modos, producida la caducidad de la licencia por alguna de las causales previstas en el régimen, si la obligatoriedad y continuidad del servicio se pudieran ver comprometidas por la desaparición del licenciatario ${ }^{82}$ el Estado podría asumir la prestación con el fin de asegurar aquellos caracteres del servicio. Justificaría además, en el caso, tal decisión, la aplicación analógica del principio que emerge del rescate impropio resultante de los marcos del gas y la energía eléctrica. Se configuraría también en esta

\footnotetext{
${ }^{80}$ Art. 4, Anexo I, decreto regl. no 1738/92; ver, también, lo establecido en el decreto 2255/92, anexo "B", Modelo de Licencia de distribución de gas, Subanexo I, Reglas Básicas: nral. 11.5; decreto 2255/92, Anexo "A", Modelo de licencia de transporte de gas; Subanexo I, Reglas Básicas: nral. 11.5.

${ }^{81}$ Art. $4^{\circ}$, ley 24.076.

82 Ténganse en cuenta, en este aspecto, la continuidad prevista en los Decretos 1185/90; 764/00 y 843/00.
}

A \& C R. de Dir. Administrativo e Constitucional, Belo Horizonte, ano 4, n. 15, p. 79-106, jan./mar. 2004 
situación un rescate impropio, determinante de una publicatio impropia.

Por lo demás, también en este caso procedería, por lo antes señalado, la revocación por razones de oportunidad, mérito o conveniencia.

e) El régimen de bienes

El régimen de la concesión del servicio de abastecimiento de agua potable y desagües cloacales contempla la transferencia de los bienes al concesionario en calidad de simple tenencia, los cuales, junto con los que se hubieran adquirido o construido durante la concesión, deben ser transferidos sin cargo al Estado al fin de aquélla. ${ }^{83}$

De la regulación de las concesiones para el transporte y distribución de energía se desprende, en cambio, que los bienes fueron transferidos en propiedad por el Estado, ${ }^{84}$ los cuales, al fin de la concesión, deben ser pagados por éste de acuerdo con el procedimiento contemplado en el contrato.

Las licencias para el transporte y distribución de gas importan la trasferencia de la propiedad de los bienes a los licenciatarios, lo cual no ha obstado para que aquellos calificados como activos esenciales - que incluyen las ampliaciones y mejoras incorporadas a la red por el licenciatario - queden sustraídos a la posibilidad de gravamen, arrendamiento, subarrendamiento o comodato, sin la autorización previa de la Autoridad Regulatoria. Al finalizar la licencia, los bienes se transfieren al Estado, libres de toda deuda, gravamen o embargo y al valor de tasación definido en el contrato de licencia. ${ }^{85}$

Finalmente, en el marco de las telecomunicaciones los bienes son también transferidos en propiedad al licenciatario, quien, sin embargo, no puede venderlos, cederlos ni transferirlos, por cualquier título o gravarlos de ninguna forma sin autorización de la Autoridad Regulatoria, siendo nulos absolutamente e inoponibles a todos los efectos de la prestación del servicio, los actos celebrados en infracción de ese requisito autorizativo. ${ }^{86}$ No está prevista expresamente la "reversión" cuando se declare eventualmente la caducidad de la licencia por razones imputables al licenciatario (única causal contemplada para la extinción). Sin embargo, si las exigencias de la

\footnotetext{
${ }^{83}$ Contrato de concesión: nral. 6.9.2.

${ }^{84}$ Según surge del llamado a concurso público nacional e internacional para la privatización de la actividad de distribución y comercialización a cargo de SEGBA, y del pliego aprobado por Resol. ME y OSP, 591/92, Anexo I del 14.7.92, numeral 11.6; opina en este mismo sentido, Karina Cicero en Servicios públicos Control y protección, Buenos Aires, Ciudad Argentina, 1996, pág. 58/59; ver, también el Contrato de concesión a Edenor: art. 120; Contrato de concesión a Transener: art. 12.

${ }^{85}$ Arts. 78, y 79, ley 24.076; Licencia de distribución: nrales. 5.7.; 11.3; 11.3.1.; 11.3.2.; Licencia de transporte; nrales. 5.7.; 11.3; 11.3 .2 .

${ }^{86}$ Decreto 62/90, Anexo 1, Pliego de bases y condiciones: Capítulo XIII, pto. 13.11.1.; pto. 13.11.2.; pto. 13.11.3.
}

A \& C R. de Dir. Administrativo e Constitucional, Belo Horizonte, ano 4, n. 15, p. 79-106, jan./mar. 2004 
continuidad del servicio determinaran el rescate impropio, el Estado podría asumir la actividad obteniendo la transferencia de los bienes mediante expropiación, sin perjuicio de acudir a la ocupación temporánea anormal hasta el perfeccionamiento de aquélla.

Como se advierte las regulaciones están lejos de responder a un criterio uniforme respecto del significado del servicio público.

Se ingresa a él por concesión (agua; transporte y distribución de energía eléctrica ${ }^{87}$ ) o por licencia (telecomunicaciones y transporte y distribución de gas natural ${ }^{88}$ ); hay concesiones con publicatio $\left(\right.$ agua $^{89}$ ) y sin ella (publicatio impropia: transporte y distribución de energía eléctrica ${ }^{90}$ y de gas natural ${ }^{91}$ ); licencias con límite en el tiempo y rescate impropio (transporte y distribución de gas natural ${ }^{92}$ ) y sin límite temporal con rescate impropio (telecomunicaciones ${ }^{93}$ ); existen concesiones sin transferencia de activos $\left(\right.$ agua $\left.^{94}\right)$ y con ella (energía eléctrica ${ }^{95}$ ) y concurren también concesiones con rescate propio $\left(\right.$ agua $^{96}$ ) y sin el (rescate impropio energía eléctrica ${ }^{97}$ y gas $^{98}$ ); finalmente hay "reversión" de bienes, en las condiciones previstas por cada marco, en el agua, la energía eléctrica y el gas; ${ }^{99}$ no así en las telecomunicaciones. ${ }^{100}$

\section{Los datos del servicio público: obligatoriedad y prestación garantizada}

¿Cuál es, entonces, la respuesta al interrogante que originó este sumario análisis? No hay, en apariencia, un dato común.

Mairal ha hallado el dato definidor en la obligatoriedad de la

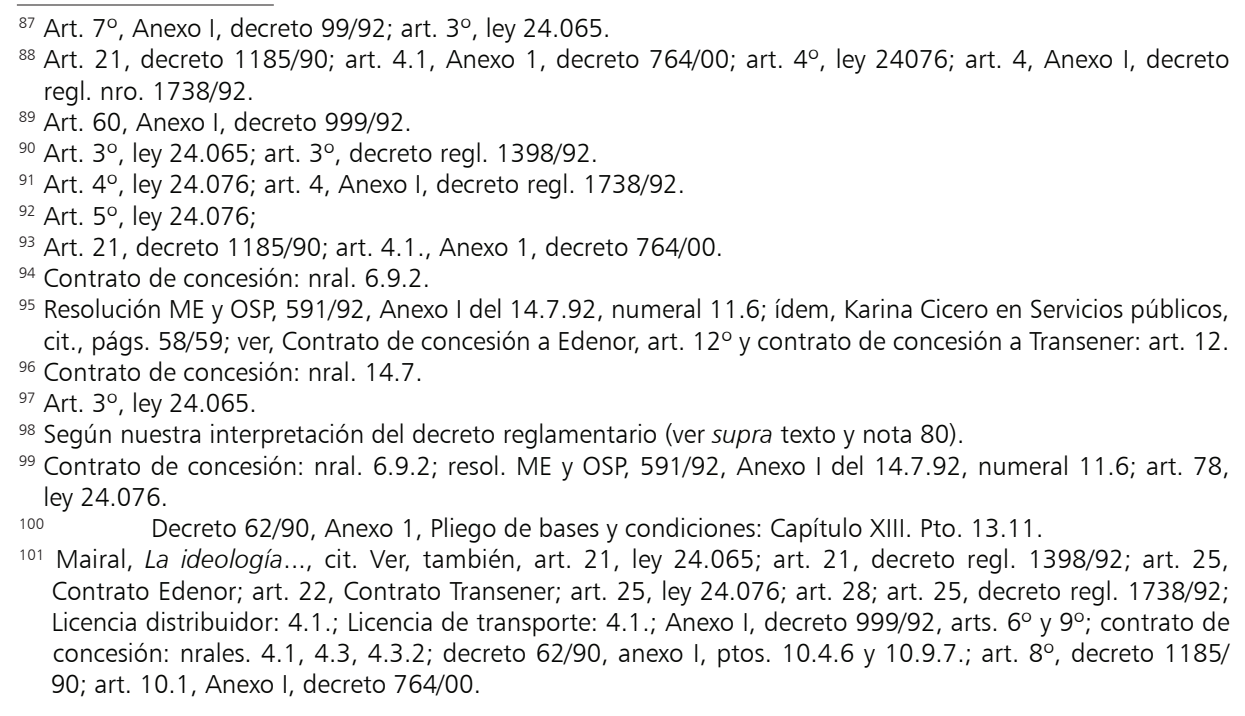

A \& C R. de Dir. Administrativo e Constitucional, Belo Horizonte, ano 4, n. 15, p. 79-106, jan./mar. 2004 
prestación que se impone al prestador en todos los casos. ${ }^{101} \mathrm{Y}$ ciertamente es éste un elemento fundamental que ya en su momento había destacado Marienhoff, cuando señalaba que los clásicos caracteres del servicio público (continuidad, regularidad, uniformidad, generalidad) se vaciaban de contenido si quien lo presta no está obligado a hacerlo ${ }^{102}$ ).

Sin embargo, esa obligatoriedad de la prestación y los consiguientes caracteres que la informan, asegurados mediante una regulación y control policial de intensidad y contenido variables según las singularidades de cada actividad no agota, a mi juicio, el contenido de la categorización, pues la obligatoriedad pesa, también, sobre el Estado, quien, cuando los privados no puedan, a su juicio, satisfacerla, debe cumplirla él mismo por vía de rescate propio o impropio.

Antes de ahora ya tuve ocasión de afirmar que si bien las privatizaciones realizadas en la década del 90 se insertaron en un marco de respuesta a la apetencia comunitaria por recuperar un protagonismo político, económico y social perdidos o gravemente restringidos y en la necesidad, asimismo, de revalorizar la eficacia como dato legitimador del ejercicio del poder, ello no podía significar el abandono por el Estado de su función de gestor del bien común y una vuelta al interesado postulado del indiferentismo global. El Estado, decía, debe asegurar la justicia debida a quienes no puedan sin culpa asumir las nuevas reglas de juego y, además, debe asegurar la transparencia de éstas. ${ }^{103}$

El Estado es imprescindible. Bruce R. Scott, profesor de la Universidad de Harvard, recordado por el autor español Juan de la Cruz Ferrer, ${ }^{104}$ señala que el progreso inicial de los paises europeos se forjó no en mercados que funcionaban en el vacío sino a partir de Estados sólidos. La integración de las economías locales fue lograda por el Estado sucesor del feudalismo, progresivamente juridizado, que generó infraestructuras y reguló el derecho de propiedad. ${ }^{105}$

El servicio público como título jurídico exorbitante propio del Derecho Administrativo, invocado por un Estado que no debe renunciar a su función gestora del bien común, es el medio de asegurar la obliga-toriedad debida al usuario, a través del control y la regulación policial o, en su caso, la prestación directa - con titularidad o sin ella — o bien indirecta.

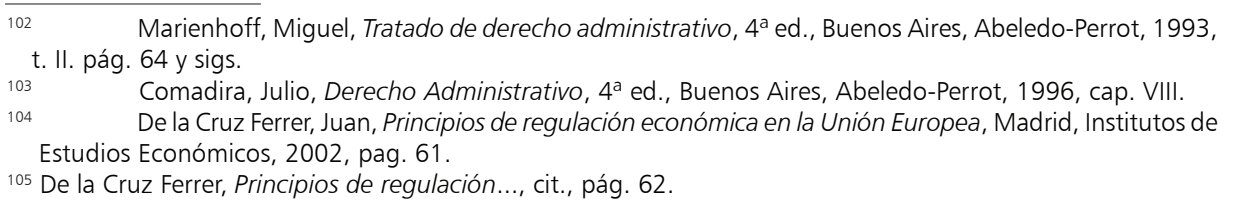

A \& C R. de Dir. Administrativo e Constitucional, Belo Horizonte, ano 4, n. 15, p. 79-106, jan./mar. 2004 
El servicio público es, pues, exorbitancia, prerrogativa y garantía. Prestación debida por el privado, pero asegurada, subsidiariamente, por el Estado. Como siempre, un Derecho Administrativo ni lo suficientemente individualista como para paralizar el servicio público, ni lo suficientemente estatista como para desconocer los derechos subjetivos del particular. ${ }^{106}$

\footnotetext{
106 Garrido Falla, La administración y la ley, en Revista de Administración Pública, Madrid, Centro de Estudios Constitucionales, sep.-dic./1951, n 6, pág. 125 y sigs., esp. pág. 129.
}

A \& C R. de Dir. Administrativo e Constitucional, Belo Horizonte, ano 4, n. 15, p. 79-106, jan./mar. 2004 